character of effective management of the department of preschool pedagogy of Ukraine of this period.

The practical significance of the work is that the materials of the dissertation can contribute to the objective interpretation of the scientific activity of the Department of Preschool Pedagogy in the Defense Institute of Ukraine (1991-2010).

The chronological boundaries of the study cover the period 1991-2010.

The lower boundary - 1991 - was caused by radical changes in the sociopolitical life of the state, the beginning of the development of the national education system.

The upper limit - 2010 is due to the adoption by the Verkhovna Rada of Ukraine of the Law "On Amendments to the Legislative Acts on General Secondary Education and Preschool Education» (May 20, 2010), the State Targeted Program for the Development of Education by 2017, the first AllUkrainian Congress of Preschool Education Workers (November 5, 2010), which exacerbated the need to move from hypothetical theories to the creation of new concepts of early childhood education.

\title{
References:
}

1. Medvid, L. A. (2003). History of national education and pedagogical thought in Ukraine: a textbook. Kyiv: Vicar. (in Ukrainian)

2. Sysoeva, S. (2011). Higher education in Ukraine: the realities of modern development: a monograph / Svetlana Sysoeva, Nina Batechko; Kiev. them. Boris Grinchenko, Nat. University of Bioresources and Environmental Management of Ukraine. Kyiv: ECMO. (in Ukrainian)

3. Kurilo, V. M., \& Shepotko V. P. (2006). Education of Ukraine and scientific and technical and social progress: history, experience, lessons: monograph. Kyiv: Demiur. (in Ukrainian)

\section{TEACHING FOREIGN LANGUAGES IN MULTILEVEL GROUPS}

\section{Oksana Semyda ${ }^{1}$}

DOI: https://doi.org/10.30525/978-9934-588-13-6-8

The globalisation process sets new requirements for the foreign language teaching in higher educational institutions as a foreign language becomes a

\footnotetext{
${ }^{1}$ National Technical University of Ukraine «I. Sikorsky Kyiv Politechnic Institute», Ukraine
} 
priority for modern students. Nowadays, language teachers are facing an extra challenge in ESP teaching as they often have to deal with large multilevel groups.

This research focuses on the problems of foreign language teaching to the multilevel classes and suggests their possible solutions. Teaching in the multilevel or mixed groups has become a sphere of interest for many scientists: J. Budden, C. C. Shank, J. Bell, C. A. Tomilson and others. The relevance of the study is stipulated by the necessity of finding new ways of teaching in different academic conditions.

First, we should define who ESP teachers are, their role and functions in the class. Scientists suggest ESP teachers to be not only language experts but to have knowledge and skills in teaching English for any technical student, be able to design teaching materials based on the content material presented by the professors, or experts in the subject area [1]. Teaching an ESP course sets special requirements to them. Their task is not only to teach language but to teach professional communication using a foreign language. This all is about forming language skills and competences that could be applied in real professional situations, that is, meeting with foreign partners, coleagues, negotiating, presenting. Among the most important tasks of the ESP teacher is choosing study material, so the teacher must be also an expert in a certain technical field and know the subject.

During ESP course teachers usually deal with the mixed groups which can be defined as a group of students with different levels of reading, writing, listening and speaking skills. Among the factors that add to the diversity of mixed classes are previous education of students, their acquired competences and psychological characteristics as well as aspirations and expectations. So, for further work a carefull assessment and analysis of the factors mentioned above should be made. In such circumstances we suggest application of differentiated approach. By differentiated teaching we understand such a teaching technique which allows to get knowledge and skills according to the level of each student. But the studying process is realised according to the same curriculum for every student.

In this context, the following difficulties the ESP teacher faces should be mentioned:

- different potential of the student group. Students are the group of people with different psychological, phisiological and study abilities, with different level of knowledge;

- lack of study materials and their poor variations. In this case teachers shourd choose and adopt material by theirselves;

- difficulties with the subject area knowledge. The ESP teacher usually does not possess sufficient knowledge on engineering subjects but the teacher 
has to promote discussions on unknown topics, create a learning eviroment and teach technical terms to the students.

In the foreign language teaching methodology the following ways of handling such issues are suggested. J. Budden suggests two different of organising the study process in the heterogeneuos class. The first one is to devide students into groups of the same level and give the tasks of appriate complexity. The second way is to deliver material targeting at the average level students [3]. Here we should mention teacher's individual work with students which is very effective and gives good results as individual tasks are always given according to the individual students' knowledge and are checked and analysed individually, so the recommendations could be given with the relevance of the student's knowledge. J. Bell emphasises the importance of pair work where the teacher can form heterogeneous and homogeneus pairs [2, p. 109]. We consider forming heterogeneous pairs and groups more effective as better students take responsibility and help "weaker» students. This kind of work motivates both strong and weak students and each student is responsible for the certain task. The effectiveness of the cooperation in such pairs or groups depends on the teacher's ability and skills to organise it and to set correct goals, choose the right tasks.

To conclude, teaching in multilevel groups is a rather complex process as it requires for careful preparation and realising difirantiated approach in the class. Different teaching techniques should be applied, different study materials should be used, be constantly developed and improved. A great role belongsto the grouping techniques and teacher's ability to plan such classes. An ESP teacher should be not only a language expert but to have knowledge of technical subjects he uses for teaching ESP.

\section{References:}

1. Ahmed, M. K. (2014). The ESP Teacher: Issues, Tasks and Challenges. English for Specific Purposes World, 42(14). Retrieved from: http:/www.esp-world.info/ Articles_42/Documents/Ahmed.pdf

2. Bell, J. (1991). Teaching multilevel classes in ESL. San Diego, CA: Dominie Press.

3. Budden, J. (2008). Adapting materials for mixed ability classes. Retrieved from: https://www.teachingenglish.org.uk/article/adapting-materials-mixed-ability-classes 